\title{
Marine and freshwater taxa: some numerical trends
}

\author{
Semyon Ya. Tsalolikhin ${ }^{1}$, Aldo Zullini2*
}

\begin{abstract}
Most of the freshwater fauna originates from ancient or recent marine ancestors. In this study, we considered only completely aquatic non-parasitic animals, counting 25 phyla, 77 classes, 363 orders for a total that should include 236,070 species. We divided these taxa into three categories: exclusively marine, marine and freshwater, and exclusively freshwater. By doing so, we obtained three distribution curves which could reflect the marine species' mode of invasion into continental waters. The lack of planktonic stages in the benthic fauna of inland waters, in addition to what we know about the effects of the impoundment of epicontinental seas following marine regressions, lead us to think that the main invasion mode into inland waters is more linked to the sea level fluctuations of the past than to slow and "voluntary" ascents of rivers by marine elements.
\end{abstract} levels.

Key words: Adaptation, freshwater biota, sea biota, taxonomic riche.

Riassunto - Taxa marini e d'acqua dolce: alcune tendenze nume-

Gran parte della fauna d'acqua dolce deriva da antenati marini antichi o recenti. Limitandoci agli animali completamente acquatici non parassiti, abbiamo contato 25 phyla, 77 classi, 363 ordini per un totale che dovrebbe comprendere 236.070 specie. Facendo una ripartizione di questi taxa in tre categorie: esclusivamente marini, marini e d'acqua dolce, ed esclusivamente d'acqua dolce, si sono ottenute tre curve di ripartizione che potrebbero riflettere la modalità d'invasione delle specie marine nelle acque continentali. La mancanza di stadi planctonici nella fauna bentonica delle acque interne e quanto sappiamo sugli effetti dell'impaludamento di tratti di mare epicontinentali in seguito alle regressioni oceaniche, ci portano a pensare che la modalità principale di invasione delle acque interne sia legata alle fluttuazioni dei livelli marini del passato più che non a lente e "volontarie" risalite dei fiumi da parte di elementi marini.

\footnotetext{
Zoological Institute of the Russian Academy of Sciences, Universitetskaya Emb. 1, 199034 Saint Petersburg, Russia. E-mail: nematoda@zin.ru

2 Università degli Studi di Milano-Bicocca, Dipartimento di Biotecnologie e Bioscienze, Piazza della Scienza 2, 20126 Milano, Italia.

*Corresponding author: aldo.zullini@unimib.it

(C) 2019 Semyon Ya. Tsalolikhin, Aldo Zullini
}

Received: 17 March 2019

Accepted for publication: 11 July 2019

Online publication: 24 October 2019
Parole chiave: Adattamento, biota d'acqua dolce, biota marino, livelli tassonomici.

\section{INTRODUCTION}

Many marine animal groups have evolved by gradually adapting to less salty waters until they became true freshwater species. This was, for some, the first step to free themselves from the water and become terrestrial animals. Of course, not all taxa have followed this path. In this paper we want to see if the taxonomic level of taxa that changed their starting habitat can help to understand the way they colonized their new environment. It is interesting to notice that there are almost no species able to live with the same biological success both in the sea and in fresh waters: these two environments are markedly different, in particular from the physiological point of view (Kültz, 2015). There are species that can be found in both environments, but their life cycle cannot be completed in only one environment (e.g. migratory fish). In other instances, the abundance of a species in one of the two environments is negligible, as we can see in some species of crustaceans, molluscs, nematodes, etc. A similar situation is also known for protists and plants. Indeed, neither single-celled organisms, nor plants have practically any species capable of equally good existence both in the sea and in fresh water. Among the very few species of animals able to shift instantaneously between salt and freshwater habitats and reproduce in either habitat, we can cite the killifish Fundulus heteroclitus (Lee \& Bell, 1999). In some rare cases, taxa of marine animals originated from freshwater ancestors: a well-known example is that of Actinopterygii (= ray-finned fish, today including about the same number of species in the sea and in fresh waters). These animals originated in inland waters (300 Mya) and only later (180 Mya) they formed the oldest known marine clade (Carrete Vega \& Wiens, 2012).

The Pangaea shelf allowed the formation of a few cosmopolitan taxa that became the taxonomic base for the present freshwater biota, beginning right after the Carboniferous regression. Transgressions and regressions of the World Ocean always occurred. A total of 119 sea level cycles, e.g., have been identified since the Triassic. Particularly strong regressions took place in the middle of the Cambrian, the middle of the Silurian, at the end of the Car- 
boniferous, in the middle of the Triassic, at the beginning of the Cretaceous, and in the middle of the Neogene (Haq et al., 1987; Hou \& Li, 2017). As far as the oceanic level fluctuations in early Palaeozoic are concerned, we noticed that the very ancient regressions failed to let clear traces in the present freshwater fauna, also because plants and animals have not colonized the continental habitats until 450 million years ago (Late Ordovician) (Gensel, 2008).

The phylogenetic relatedness between freshwater and marine taxa is determined by the age of the vicariant event, which originated the freshwater lineage. No Cambrian freshwater trilobites are known, although trilobites made up $60 \%$ of the entire Cambrian macrofauna. Similarly, no freshwater archaeocyathids (30\% of the Cambrian macrofauna) are known.

We cannot follow the habitat evolution of certain taxa devoid of hard structures able to leave fossil residues, but sometimes, in the absence of paleontological evidence, a "replacement method", based on the recognition of an ecosystemic transition to a new habitat can be applied. If, e.g., we are interested in the history of an ecologically significant animal group with no traces in the fossil record, we can study instead an ecological equivalent with fossil remains. The "alleles" nematode-ostracods can be quoted as an example. Nematodes are, from the paleontological point of view, "devoid of history" because they are rarely preserved in the fossil state (Poinar, 2011); ostracods, on the contrary, left a distinct and rich trace in the fossil record. So, we can assume ostracods as representative (proxies) of the whole aquatic meiofauna. They inhabit both sea (ca. recent 11,000 species) and inland waters (ca. 2,000 species). Marine ostracods have been known since upper Cambrian, while the freshwater ones appeared during the Devonian and become well diversified during the Carboniferous. Moreover, the first interstitial freshwater ostracods are known only since 40 Mya onwards (Danielpol, 1980). The appearance of new ostracod taxa was always coincident with ocean regressions and their colonization of inland waters was more intensive during the existence of the Pangaea (Danielpol, 1980; De Deckker et al., 1988; Martens et al. 2008). Ostracods and nematodes occupy almost the same microhabitats in water bodies, have a similar food spectrum, and have life cycles of similar duration with a comparable number of eggs. There is reason to believe that nematodes, being one of the components of the established shallow shelf ecosystem of Pangaea, colonized freshwater in the same way (Giere, 2009).

Another interesting relationship can be traced by linking separate groups of nematodes with certain groups of algae. For example, many marine and freshwater nematodes of the Chromadoridae family feed, almost exclusively, on diatoms. The structure of their oral apparatus is provided with a tooth used as a "can opener" to split the siliceous shell of diatoms. The content of the cell is ingested, and the shell is "spat out" (Jensen, 1987). If chromadorids are so specialized in consuming diatoms, then it is probable that they always lived together. As for diatoms, they appeared only in the Jurassic or, according to the molecular clock, in the Triassic, and they have invaded freshwater bodies only since the middle Eocene or, according to some authors, since the Late Cretaceous (Kooistra et al., 2007).
If we consider as true aquatic animals those reproducing and spending their whole life in water, we will be struck by the fact that a conspicuous part of them (about $20 \%$ of species) is living in fresh water, despite the fact that inland waters on our planet are less than $0.01 \%$ of the sea water by volume (Gleick, 1993). All phyla (Budd, 2003) and most freshwater taxa descend from more or less distant marine ancestors and it is interesting to investigate how many species and higher taxa invaded the continental waters. Over the course of time, the pioneer species adapting to fresh water formed well adapted freshwater species that often differentiated into various genera and, with sufficient time and efficient selection, forming also freshwater families, orders and classes (Lee \& Bell, 1999).

\section{METHODS}

In 2013, Zhi-Qiang Zhang estimated that a total of $1,525,728$ extant animal species, divided in 40 phyla, were known. In the present paper we are not going to consider extinct taxa, because their status is usually not comparable with that of the extant ones, and because their living habitat is often doubtful. We are only going to deal with contemporary free-living completely aquatic metazoan, excluding therefore insects and the terrestrial phylum of Onychophora. Many insects have at least one aquatic stage, but all of them have terrestrial ancestors, their aquatic phase being a late adaptation. Even their respiratory system, despite the gills of the Ephemeroptera and other aquatic larvae, is basically designed for aerial respiration. Moreover, there are very few groups of terrestrial crustaceans breathing air, therefore we neglected them in our analysis. Moreover, we are going to overlook some very small and discussed phyla (often considered as subphyla) with less than 20 species, such as Phoronidea (phylum with no class nor order names) or the interesting phylum (but often considered as a class) of Micrognatozoa with one known species only. We also excluded parasites because of their non-independent habitat history and their often-uncertain taxonomic position, e.g. Myxozoa, Polypodium, most of platyhelminthts, many nematodes, etc. This way, we are only going to consider 25 animal phyla. To give further information, we are going to add the approximate number of the known species (after exclusion of parasites, of semiterrestrial, and non-extant species) living both in marine and fresh water (Tab. 1). We took these numbers and taxonomy from various authors, mainly from Balian et al. (2008), Mora et al. (2011) and Zhi-Qiang Zhang (2013).

We are fully aware that the Linnaean taxonomic levels are rather arbitrary (Gauthier et al. 1988), e.g. the vertebrate classes or orders are hardly comparable with the arthropod classes or orders. Nevertheless, the taxonomic categories represent some of the most important nodes in the fractal dendrogram of the evolutionary tree. Therefore, we can use them as indicators of the rate at which many different marine taxa adapted to the freshwater life. Moreover, as stated by Gaston (2000), higher taxa are not arbitrary units, tending to comprise species that are more closely related than would be expected by chance (for the higher-taxon richness as a proxy for diversity value, see Williams et al. 
Tab. 1 - Estimated known number of the strict aquatic species (marine and fresh water) of animal phyla, excluding parasites species, and excluding phyla with less than 20 known species.

\begin{tabular}{|l|r|r|}
\hline Phylum & Marine spp. & FW spp. \\
\hline Xenacoelomorpha & 430 & 2 \\
\hline Porifera & 10,700 & 220 \\
\hline Cnidaria & 16,300 & 40 \\
\hline Ctenophora & 190 & 0 \\
\hline Platyhelminthes & 5,200 & 1,300 \\
\hline Gnathostomulida & 100 & 0 \\
\hline Nemertea & 1,300 & 20 \\
\hline Mollusca & 60,700 & 5,000 \\
\hline Gastrotricha & 370 & 320 \\
\hline Kinorhyncha & 200 & 0 \\
\hline Loricifera & 40 & 0 \\
\hline Nematoda & 5,960 & 1,890 \\
\hline Priapulida & 20 & 0 \\
\hline Rotifera & 70 & 1,950 \\
\hline Annelida & 9,300 & 1,750 \\
\hline Sipuncula & 150 & 0 \\
\hline Tardigrada & 200 & 60 \\
\hline Arthropoda & 48,600 & 17,700 \\
\hline Brachipoda & 400 & 0 \\
\hline Bryozoa & 6,000 & 90 \\
\hline Entoprocta & 170 & 2 \\
\hline Chaetognatha & 170 & 0 \\
\hline Echinodermata & $\mathbf{7 , 5 0 0}$ & 0 \\
\hline Hemichordata & 130 & 0 \\
\hline Chordata & & 14,130 \\
\hline Total & $\mathbf{4 4 , 4 7 0}$ \\
\hline
\end{tabular}

1997). We also think that different choices, e.g. selecting nodes from the animal phylogenetic cladogram instead of Linnaean categories (de Queiroz \& Gauthier, 1990; 1994), would give not very different results from ours.

We calculated, for all free-living known aquatic animals, the habitat proportions of phyla, classes, orders and species. We analysed our data with the Clopper-Pearson method to allow the calculation of the confidence interval of a proportion by weighing its position, with respect to 0 or 1 , of the range of values it can assume (Suchéras-Marx et al., 2019).

\section{RESULTS}

For the animals taken into consideration (Methods section), we counted a total of 25 phyla, 77 classes, 363 orders and 236,070 species. The values concerning families and genera, being too numerous and difficult to ascertain, are here interpolated. We call "amphibiotic" the taxa including both marine and freshwater species, whereas "marine" and "freshwater" taxa refer to taxa exclusive for their respective environment. Consulting Balian et al. (2008), the online Catalogue of Life (retrieved from https://www.catalogueoflife.org/), and their links to numerous specialized papers, we found that exclusively marine taxa are 11 phyla, 48 classes, 260 orders, and 191,600 species. Amphibiotic taxa are 14 phyla, 28 classes, 72 orders, and a negligible number of species. Exclusively freshwater taxa are 0 phyla, 2 classes, 31 orders, and 44,470 species. To normalize data, we transformed these numbers in percentages (Fig. 1). Applying the z-test, all pair comparisons between marine, amphibiotic and freshwater taxonomic levels are highly significant, except for the number of phyla for marine vs. amphibiotic taxa (Tab. 2 and Fig. 2).

We found that $56 \%$ of the aquatic phyla have representatives in both marine and fresh waters and this percentage decreases to $36 \%$ for classes, $20 \%$ for orders, down to species level where very few species are able to live in both environments (we approximate them to zero) (Fig. 1). Already in 1949, Birstein, studying the process of adaptation of marine species to fresh water, had noticed that at the level of genus and species there are more cases of specialization for the habitat (marine or freshwater) than at the level of phylum or class.

Since the percentage of exclusive freshwater taxa increases from phyla to species level, this trend is at first sight expressed by a straight line (named FRESHWATER in Fig. 1). This line goes from the proportion of metazoan species of $19 \%$ exclusively present in freshwater, intersecting the amphibiotic curve in a point at about $10 \%$ level of the vertical axis and at an intermediate level between family and order (on the horizontal axis). If we put these data in another form (Fig. 3) perhaps easier to represent our results, the main part of the graphic is occupied

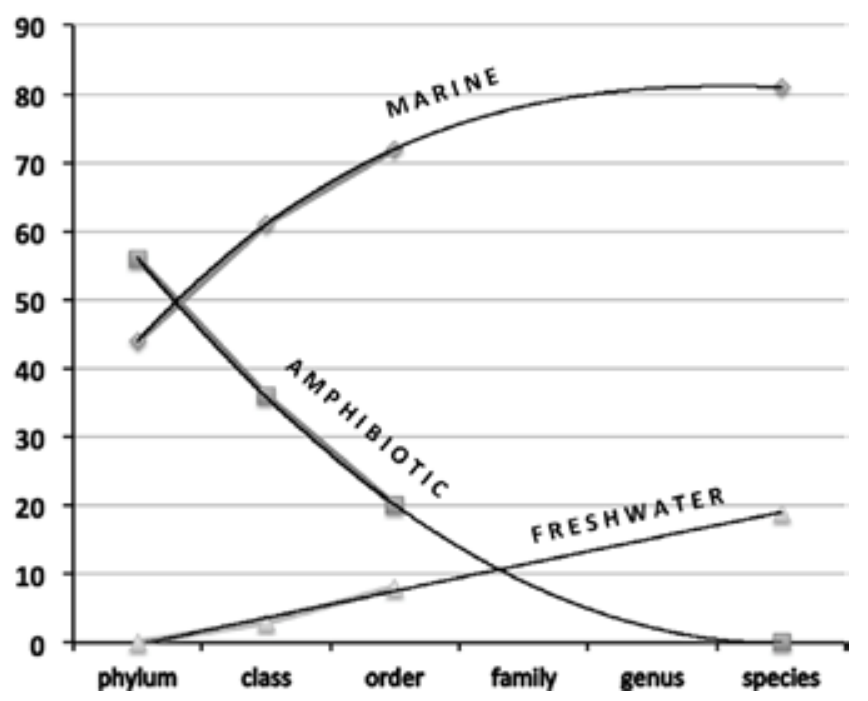

Fig. 1 - Relative abundance of marine, amphibiotic and freshwater taxa. (Abscissa - taxa; ordinate - relative number of taxa in percent). 
Tab. 2 - $|z|$ values of the pair comparisons and, in brackets, the P-value approach. In all cases, the null hypothesis (= no significant difference between the two values) is rejected, except in the comparison between the number of marine $v s$. amphibiotic phyla. The empty boxes correspond to trivial or senseless comparisons. In bold: significant differences; in italics: no significant difference (= the null hypothesis, or a casual difference, cannot be excluded).

\begin{tabular}{|c|c|c|c|}
\hline \multirow{2}{*}{$\begin{array}{c}|z| \text { limit for } 5 \% \text { significance } \\
\qquad|z|=1.96\end{array}$} & \multicolumn{3}{|c|}{$|z|$ values } \\
\hline & $\begin{array}{c}\underset{*}{\text { Marine }} \\
\text { Amphibiotic }\end{array}$ & $\begin{array}{c}\underset{*}{\text { Marine }} \\
\text { Freshwater }\end{array}$ & $\begin{array}{l}\underset{*}{\text { Amphibiotic }} \\
\text { Freshwater }\end{array}$ \\
\hline Phyla & $0.085(39.6 \%)$ & - & - \\
\hline Classes & $3.2(0.14 \%)$ & - & - \\
\hline Orders & $14(<0.0001 \%)$ & $17.3(<0.0001 \%)$ & $4.4(<0.001 \%)$ \\
\hline Species & - & $428.2(<0.000001 \%)$ & - \\
\hline
\end{tabular}
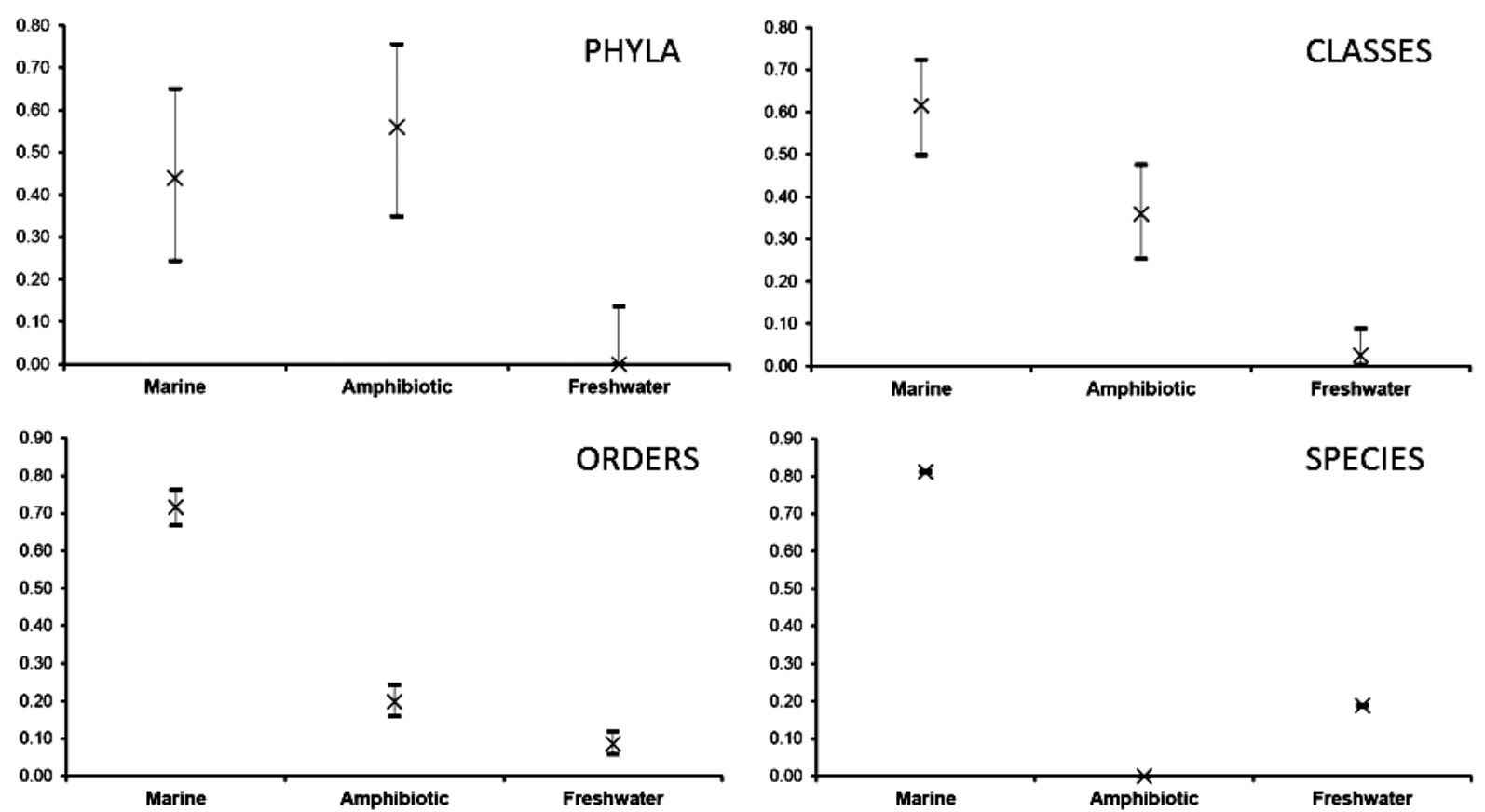

Fig. 2 - Confidence intervals of the previous data illustrated by the Clopper-Pearson method. On the y axis: Frequency.

by marine taxa, secondly by the triangle correspondent to amphibiotic taxa, and finally by a smaller area of freshwater taxa. The fact that no pure freshwater, but pure marine phyla exist, reflects the marine origin of all phyla and their secondary adaptation to freshwater (and terrestrial) environments.

In Fig. 3 we see that pure marine taxa percentages from the family to the species interval do not change their values (see the almost horizontal line at about $80 \%$ of the vertical axis), while in the meantime the pure freshwater metazoan taxa percentage increases. On the extreme right of the diagram we also see that there are no animal species living both in the sea and in fresh water. In this diagram we also notice that, starting from the family and order levels, the marine and freshwater curves of the diagram clearly diverge. Obviously, this is due to the presence of the amphibiotic taxa. If we assume, on a scale of geological time, a fairly uniform penetration of marine organisms through estuaries into rivers, such configuration should be different and we should see in Fig. 3 a straight line ranging from $44 \%$ (proportion of marine phyla) to $81 \%$ (proportion of marine species). There would be no reduction in the relative number of amphibiotic genera compared to the number of families, since the number of such genera would be continuously replenished by invaders from the sea. The continuous process of taxogenesis should maintain a certain percentage stability of marine taxa, and the continuous invasion into inland waters should maintain such stability in the amphibiotic taxa, but this fact is not observed. 


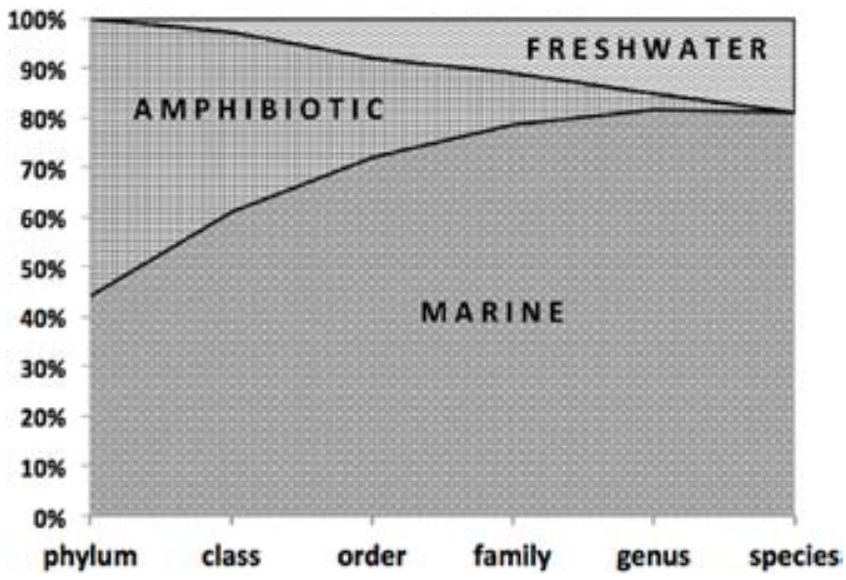

Fig. 3 - The interdependence of marine, amphibiotic and freshwater fauna at different taxa levels.

\section{DISCUSSION}

We observe a clear reduction in the percentage of younger (= species, genus, family) amphibiotic taxonomic levels, with an increase in the younger freshwater ones. We can explain this by supposing that there are occasional and rare massive introductions of marine species into fresh water habitats.

There are some evidences for our interpretation, e.g. what was observed in the Zuiderzee. The North Sea forms, in the Netherlands, a gulf of $5,000 \mathrm{~km}^{2}$ called Zuiderzee (literally: Southern sea) where, in the year 1932, a $32 \mathrm{~km}$ long dam isolated this stretch of sea which, over the course of the following years, gradually converted into a freshwater basin, which is now called IJssel Lake. Most of the marine fauna disappeared, but some species (namely, one species of hydrozoans and four species of crustaceans, of which one copepod, one amphipod, one isopod, and one mysid) adapted to the new freshwater habitat (Lee \& Bell, 1999). All this demonstrates the possibility that, following a gradual desalination of water during various geological events, large stretches of sea enclosed within the continents may give rise to faunas well adapted to fresh water. This is all truer if the process is slower than in the reported artificial case, in which only a few species were able to cope with rapid changes. Cases of marine taxa invading continental basins by gradually becoming endemic or freshwater are well documented (Penzo et al., 1998; Yamanoue et al., 2011; Lukeneder et al., 2011; Mamos et al., 2016; Hou \& Li, 2017).

Another evidence that proves that the bay or lagoon impoundment (and desalination of water) is the main route for the formation of freshwater benthic fauna, lies in the fact that the latter usually loses planktonic larval stages. This phenomenon seems to be linked to the fact that a plankton larva could hardly go up the current through the river estuaries of the rivers and be able to reach and settle the continental water basins. Therefore, we can understand why in the inland waters, sponges, cnidarians, flatworms, molluscs, and annelids, are almost always devoid of planktonic larvae. Once an inland water body has been colonized, the marine benthic fauna surviving the progressive desalination no longer needs to expand into vast are- as (which are not there) and over time loses its planktonic larval stage. Naturally, there are exceptions: for example, the cnidarians, usually represented in the fresh waters by Hydra and allied genera with no planktonic stages (such as planula and medusa), are also represented by Craspedacusta, which in addition to the polyp stage, also keeps planula and medusa in its life cycle. Another logic applies to the holoplanktonic organisms, which, in inland waters, are mainly represented by rotifers, cladocera and copepods. In fact, they can probably invade internal waters, always remaining planktonic, thanks to their very fast life turnover and/or the transport by aquatic birds. For six of the 10 orders of copepods, a minimum of 22 independent colonisations of inland waters has been demonstrated by Boxhall \& Jaume (2000), but without specifying their mode and mechanism of invasion. In a single copepod family (Centropagidae), at least five separate invasions were confirmed by DNA analysis (Adamowicz et al., 2010). Our interpretation of the invasion way of marine animals into inland waters implies that the sea-freshwater transition is a relatively infrequent phenomenon (since it corresponds to marine regressions), while small continuous invasions should be much more numerous, since they occur without interruption during the entire geological eras. Molecular analyses on bacteria and protists (Logares et al., 2007), which have also excellent dispersion abilities, reinforce our interpretation, as also appears from the title of an article (Infrequent marine-freshwater transitions in the microbial world) by Logares et al. (2009).

What looks like a counterexample is provided by Dreissena polymorpha. This bivalve mollusc originated in the brackish waters of Paratethys (shallow marginal sea existing from the Late Jurassic to the Pliocene), which favoured its spreading into Europe. Dreissena polymorpha was then eliminated by the Quaternary glaciations and survived only in the region comprising Aral, Caspian Sea and Black Sea (all remnants of the ancient Paratethys). This mollusc remained confined in this region for thousands of years since, we believe, its planktonic larval stage (veliger) was of little use to the upstream colonization of the river networks. It was only from 1824 (the year in which this species was discovered in London) that it began its invasion of all the European rivers and lakes until, since 1985, it started to colonize North America, too. All these recent invasions, however, have been made possible only by the inadvertent transport by vessels linked to the international trade (Johnson \& Carlton, 1996; Bij de Vate et al., 2002). Also, other research stresses the crucial role of fluvial navigation in the modern dispersal of freshwater animals(e.g., Nesemann et al., 1995). It is interesting to note that Dreissena polymorpha, originally inhabiting the somewhat salty (brackish) waters (6-10\% salinity) of its native Ponto-Caspian region, gradually became more and more adaptable to fresh water to the point of not being able to tolerate, in its North American populations, a salinity above 4\%o (McMahon, 1996).

It is probable that the origin of freshwater biota took place in a complex, ecosystemic way. This means that amphibiotic condition of all taxa occurs synchronically, by a process we call limno-accretion (from the Greek limne = lake, and Latin accretio = increment, addition) and that 
the whole biota evolves adapting itself to its new physical situations. At first, there are some given species becoming purely freshwater, then their number grows occupying different ecological niches and, over time, they form new genera and higher taxa. The most plausible scenario for such a phenomenon is the powerful transgressions of the World Ocean creating vast shallow epicontinental seas inhabited by a certain faunal complex. At the next stage, the regressions of the Ocean leave behind vast seas and lakes slowly becoming freshwater because of the river inputs (Tsalolikhin, 1992). It should be emphasized that we are talking about the historical process of the formation of the biota of primary water organisms. The whole process of the freshwater formation can be described by the two Boucot's (1975) rules:

1) On the shelves of ancient continental platforms, populations of shallow-water organisms reached enormous proportions, becoming cosmopolitan, i.e. adapted to unstable conditions and became significantly more durable on a geological time scale than taxa occupying small areas (cosmopolitan taxa are such in space as well as in time).

2) Under conditions of fluctuation of physical factors, a decrease in taxonomic diversity is observed.

We know that, according to the moderate stress theory (Maestre et al., 2009), variations of ecological parameters increase the biodiversity provided that they are not excessive. The second Boucot's rule obviously refers to an excess of variability.

Considering the long time elapsed since the upper boundary of the Palaeozoic (250 million years ago) we would expect a higher percentage of exclusive freshwater orders, classes and phyla than shown in Fig. 1. In fact, in the sea and in terrestrial environment not only orders, but also classes usually appear in a much shorter time interval. Clearly, the evolution of higher taxa requires a long space-time continuum which cannot exist in inland waters. The disappearance of one water body and the development of migrants into another water body causes a "start all over again" in the process of forming a hierarchical structure of populations. This does not happen at sea or on land. The extant freshwater orders (and in part families) must have formed a long time ago, during the existence of Pangaea (from Carboniferous to Jurassic) as evidenced by their distribution in the inland waters of the globe. In our graph (Fig. 1) the sum obtained from the correspondent taxa levels of the amphibiont curve to the freshwater straight line is $28 \%$ for orders, $21 \%$ for families, and $19 \%$ for species. In other words, pure marine fauna from family to species level represents approximately $80 \%$ of the whole aquatic fauna.

According to Müller et al. (2008), the continents were inundated by shallow seas (epicontinental seas) when oceans reached their maximum level (about 170 $\mathrm{m}$ higher than today) during Cretaceous, from 120 to 80 million years ago. After that, from 80 to 30 million years ago, a continuous lowering of the ocean level ensued. This meant a 3.3\% decrease of the global oceanic area, corresponding to a loss of about $1 \times 10^{6} \mathrm{~km}^{2}$. This trend was punctuated by many minor and short sea level cycles (Haq et al., 1987). In the early Eocene (55-50 Mya), the sea level rose almost $100 \mathrm{~m}$ followed by a long-term decrease owing to Eocene-Oligocene Antarctic glaciations and, after Pliocene, the sea-level changed of 60-120 m as a result of Quaternary glaciations (Hou \& Li, 2017). In general, we can assume that, especially after the Late Cretaceous, vast saltwater basins remained trapped in the continents, then becoming gradually freshwater due the fluvial contribution. Paratethys, e.g., shifted from marine to freshwater habitat about 12 Mya (mid Miocene) originating the extant Ponto-Caspian molluscs and crustaceans (Hou \& Li, 2017). Another interesting example concerns the rather well studied group of Palaemoninae (Crustacea), which shows a minimum of ten independent invasions into inland waters, since these species have independently evolved such adaptations in all major biogeographic regions (Ashelby et al., 2012).

Benthic communities in brackish water have fewer species than either marine or freshwater communities (Remane \& Schlieper, 1972). Nematodes, e.g., inhabiting brackish water sediments show a minimum number of species at the 3-7\%o salinity range even when their population density is high. A similar pattern is valid in general for all animal taxa. In conclusion, it is not clear if brackish water nematode species truly exist (Ferris \& Ferris, 1979; Heip et al., 1985). However, our present interest is not focused on this kind of eco-physiological problems, but on the propensity of various taxa to adopt either both marine and freshwater environments, or one environment only. The evolutionary scenario concerning adaptation to freshwater life is sufficiently known for only a few taxonomic groups, such as fish, molluscs and crustaceans (Mamos et al., 2016). Among crustaceans, the freshwater Gammarus balcanicus group, whose genus is marine in origin, undertook a long process of diversification spanning nearly 15 Mya of the Paratethys regression. Pleistocene glaciations, instead, had only a superficial influence on the already well-diversified species of this group (Mamos et al., 2016). Macrobrachium, another mainly freshwater crustacean genus, has a completely different history and distribution, yet the average time of divergence between species is in 11-16 Mya, early Miocene (Murphy \& Austin, 2005). The transition from marine and freshwater fauna into subterranean habitats is discussed by Rouch \& Danielpol (1987).

\section{CONCLUSIONS}

The taxa proportions we found among sea and freshwater animals are coherent with a non-single continuous adaptation towards inland water environments. Our data, instead, are those that one can expect if the origin and development of the freshwater biota is not the result of a continuous gradual invasion and adaptation of occasional single marine species, but the result of rather rapid adaptations of whole communities to freshwater habitats. This occurred over the course of several stages strictly related to as many oceanic regressions. This view is analogous, in the phylogenetic field, to that in which the importance of rapid evolutionary changes (punctuated equilibria) is 
stressed as an alternative to the traditional concept of slow and constant changes (phyletic gradualism) (Eldredge \& Gould, 1972).

\section{Acknowledgments}

The useful suggestions of three anonymous reviewers were substantial to significantly improve our text. We also thank Guido Pacchetti for the statistical help, and Maria Angelica Casazza for the English revision.

\section{REFERENCES}

Adamowicz S.J., Menu-Marque S., Halse S.A., Topan J.C., Zemlak T.S., Herbert P.D.N. \& Witt J.D.S., 2010 The evolutionary diversification of the Centropagidae (Crustacea, Calanoida): a history of habitat shifts. $\mathrm{Mo}$ lecular Phylogenetics and Evolution, 55: 418-430.

Ashelby C.W., Page T.J., De Grave S., Huges J.M. \& Johnson M.L., 2012 - Regional scale speciation reveals multiple invasions of freshwater in Palaemoninae (Decapoda). Zoologica Scripta, 41: 293-306.

Balian E.V., Lévêque C., Segers H. \& Martens K. (eds.), 2008 - Freshwater animal diversity assessment. Hydrobiologia, 595: 1- 637.

Bij de Vaate A., Jazdzewski K., Katelaars H.A.M., Gollash S. \& Van der Velde G., 2002 - Geographical patterns in range extension of Ponto-Caspian macroinvertebrate species in Europe. Canadian Journal of Fisheries and Aquatic Sciences, 59: 1159-1174.

Birstein Ya.A., 1949 - Some problems of the origin and evolution of the freshwater fauna (in Russian). Uspechi Sovr. Biologii, 27: 119-140.

Boucot A.J, 1975 - Evolution and extinction rate controls. Elsevier.

Boxhall G.A. \& Jaume D., 2000 - Making waves: the repeated colonization of fresh water by Copepod Crustaceans. Advances in Ecological Research, 31: 61-79.

Budd G.E., 2003 - The Cambrian fossil record and the origin of the phyla. Integrative and Comparative Biology, 43: 157-165.

Carrete Vega G. \& Wiens J.J., 2012 - Why are there so few fish in the sea? Proceedings of the Royal Society, $B, 279: 2323-2329$.

Danielpol D.L., 1980 - An essay to assess the age of the freshwater interstitial ostracods in Europe. Bijdragen tot de Dierkunde, 50: 243-291.

De Deckker P., Chivas A.R. \& Shelley M.G., 1988 Paleoenvironment of the Messinian Mediterranean 'Lago Mare' from strontium and magnesium in ostracode shells. Palaios, 3: 352-358.

de Queiroz K. \& Gauthier J., 1990 - Phylogeny as a central principle in taxonomy: phylogenetics definitions of taxon names. Systematic Zoology, 39: 307-322.

de Queiroz K. \& Gauthier J., 1994 - Toward a phylogenetic system of biological nomenclature. Trends in Ecology and Evolution, 9: 27-31.

Eldredge N. \& Gould J.S., 1972 - Punctuated equilibria: an alternative to phyletic gradualism. In: Models in Paleobiology. T.J.M. Schopf (ed.). Freeman Cooper: 82-115.
Ferris V.R. \& Ferris J.M., 1979 - Thread worms (Nematoda). In: Pollution ecology of estuarine invertebrates. Hart C.W. \& Fuller S.L.H. (eds.). Academic Press: $1-33$.

Gaston K.J., 2000 - Biodiversity: higher taxon richness. Progress in Physical Geography, 24: 117-127.

Gauthier J., Kluge A.G. \& Rowe T., 1988 - Amniote phylogeny and the importance of fossils. Cladistics, 4 : 105-209.

Gensel P.G., 2008 - The earliest land plants. Annual Review of Ecology, Evolution, and Systematics, 39: 459477.

Giere O., 2009 - Meiobenthology. The microscopic motile fauna of aquatic sediments. Springer-Verlag.

Gleick P.H. (ed.), 1993 - Water in crisis: a guide to the world's freshwater resources. Oxford University Press.

Haq B.U., Hardenbol J. \& Vail P.R., 1987 - Chronology of fluctuating sea levels since the Triassic. Science, 235: 1156-1166.

Heip C., Vincx M. \& Vranken G., 1985 - The ecology of marine nematodes. Oceanography and Marine Biology. An Annual Review, 23: 399-489.

Hou Z. \& Li S., 2017 - Tethyan changes shaped aquatic diversification. Biological Reviews: 23. < doi: 10.1111/ brv.12376>

Jensen P., 1987 - Feeding ecology of free-living aquatic nematodes. Marine Ecology. Prog. Ser., 35: 187-196.

Johnson L.E. \& Carlton J.T., 1996 - Post-establishment spread in large-scale invasions: dispersal mechanisms of the zebra mussel Dreissena polymorpha. Ecology, 77: 1686-1690.

Kooistra W.H.C.F, Gersonde R., Medlin L.K. \& Mann, D.G., 2007 - The origin and evolution of the diatoms: their adaptation to a planktonic existence. In: Evolution of Primary Producers in the Sea. Falkowski, P.G., \& Knoll A.H. (eds.). Academic Press: 207-249.

Kültz D., 2015 - Physiological mechanisms used by fish to cope with salinity stress. The Journal of Experimental Biology, 218: 1907-1914.

Lee C.E. \& Bell M.A., 1999 - Causes and consequences of recent freshwater invasions by saltwater animals. Trends in Ecology \& Evolution, 14 (7): 284-288. <doi: 10.1016/S0169-5347(99)01596-7>

Logares R., Brate J., Bertilsson S., Clasen J.L., ShalchianTabrizi K. \& Rengefors K., 2009 - Infrequent marinefreshwater transitions in the microbial world. Trends in Microbiology, 17: 414-422.

Logares R, Shalchian-Tabrizi K., Boltovskoy A. \& Rengefors K., 2007 - Extensive dinoflagellate phylogenies indicate infrequent marine-freshwater transitions. Molecular Phylogenetics and Evolution, 45: 887-903.

Lukeneder S., Zuschin M., Harzhauser M. \& Mandic O., 2011 - Spatiotemporal Signals and Palaeoenvironments of Endemic Molluscan Assemblages in the Marine System of the Sarmatian Paratethys. Acta Palaeontologica Polonica, 56: 767-784.

Maestre F.T., Callaway R.M., Valladares F. \& Lortie C.J., 2009 - Refining the stress-gradient hypothesis for competition and facilitation in plant communities. Journal of Ecology, 97: 199-205. 
Mamos T., Wattier R., Burzynski A. \& Grabowski M., 2016 - The legacy of a vanished sea: a high level of diversification within a European freshwater amphipod species complex driven by $15 \mathrm{My}$ of Paratethys regression. Molecular Ecology, 25 (3): 795-810. < doi: 10.1111/mec.13499>

Martens K., Schön I., Meisch C. \& Horne D.J., 2008 Global diversity of ostracods (Ostracoda, Crustacea) in freshwater. In: Freshwater Animal Diversity Assessment. Balian, E.V., Lévêque C., Segers, H., \& Martens, K. (eds.). Hydrobiologia, 595, 185-193.

McMahon R.F., 1996 - The physiological ecology of zebra mussel, Dreissena polymorpha, in North America and Europe. American Zoologist, 36: 339-363.

Mora C., Tittensor D.P., Adl S., Simpson A.G.B. \& Worm B., 2011 - How many species are there on earth and in the ocean? PLOS Biology. <https://doi.org/10.1371/ journal.pbio.1001127>

Müller R.D., Sdrolias M., Gaina C., Steinberger B. \& Heine C., 2008 - Long-term sea-level fluctuations driven by ocean basin dynamics. Science, 319: 13571362.

Murphy N.P. \& Austin C.M., 2005 - Phylogenetic relationships of the globally distributed freshwater prawn genus Macrobrachium (Crustacea: Decapoda: Palaemonidae): biogeography, taxonomy and the convergent evolution of abbreviated larval development. Zoologica Scripta, 34: 187-197.

Nesemann H., Pöckl M. \& Wittmann K.J., 1995 - Distribution of epigean Malacostraca in the middle and upper Danube (Hungary, Austria, Germany). Miscellanea Zoologica Hungarica, 10: 49-68.

Penzo E., Gandolfi G., Bargelloni L., Colombo L. \& Patarnello T., 1998 - Messinian salinity crisis and the origin of freshwater lifestyle in Western Mediterranean gobies. Molecular Biology and Evolution, 15: 1472-1480.

Poinar G.O. Jr., 2011 - The Evolutionary History of Nematodes. As revealed in stone, amber and mummies. Nematology Monographs and Perspectives, Brill, 9.

Remane A. \& Schlieper C., 1972 - Biology of brackish water. Die Binnengewässer, 25.

Rouch R. \& Danielpol D.L., 1987 - L'origine de dal faune aquatique souterraine, entre le paradigm du refuge et le modèle de la colonisation active. Stygologia, 3: 345372.

Suchéras-Marx B., Escarguel G., Ferreira J. \& Hammer Ø., 2019 - Statistical confidence intervals for relative abundances and abundance-based ratios: simple practical solutions for an old overlooked question. Marine Micropaleontology, 151. <doi:10.1016/j. marmicro.2019.101751>

Tsalolikhin S.Ya., 1992 - From biological diversity to historic biocoenology (in Russian). In: Biologiceskoe Rasnobraznie: podchodi k izucenio i sochraneneiu. Akademia Nauk, 101-110.

Williams P.H., Gaston K.J. \& Humphries C.J., 1997 Mapping biodiversity value worldwide: combining higher-taxon richness from different groups. Proceedings of the Royal Society B: Biological Sciences, 264: 141-148.
Yamanoue Y., Miya M., Doi H., Mabuchi K., Sakai H. \& Nishida M., 2011 - Multiple Invasions into Freshwater by Pufferfishes (Teleostei: Tetraodontidae): A Mitogenomic Perspective. PLoS ONE, 6 (2): e17410.

Zhi-Qiang Z, 2013 - Animal biodiversity: an update of classification and diversity in 2013. In: Animal biodiversity: an outline of higher-level classification and survey of taxonomic richness (addenda 2013). Zootaxa, 3703: 1-82. 
APPENDIX - Taxa taken into consideration and their distribution in the three categories: exclusively marine (Sea), marine and freshwater (Amphi), exclusively freshwater (FW).

\begin{tabular}{|c|c|c|c|c|c|}
\hline Phylum & Class & Order & Sea & Amphi & FW \\
\hline \multirow[t]{39}{*}{ Chordata } & Leptocardii & Amphioxiformes & $\mathbf{x}$ & & \\
\hline & Ascidiacea & Enterogona & $\mathbf{x}$ & & \\
\hline & & Pleurogona & $\mathbf{x}$ & & \\
\hline & & Aspiraculata & $\mathbf{x}$ & & \\
\hline & Thaliacea & Doliolida & $\mathbf{x}$ & & \\
\hline & & Pyrosomida & $\mathbf{x}$ & & \\
\hline & & Salpida & $\mathbf{x}$ & & \\
\hline & Appendicularia & Larvacea & $\mathbf{x}$ & & \\
\hline & Myxini & Myxiniformes & $\mathbf{x}$ & & \\
\hline & Petromyzontida & Petromyzontiformes & & $\mathbf{x}$ & \\
\hline & Chondrichthyes & Rajiformes & & $\mathbf{x}$ & \\
\hline & & Pristiformes & $\mathbf{x}$ & & \\
\hline & & Torpediniformes & $\mathbf{x}$ & & \\
\hline & & Myliobatiformes & & $\mathbf{x}$ & \\
\hline & & Heterodontiformes & $\mathbf{x}$ & & \\
\hline & & Orectolobiformes & $\mathbf{x}$ & & \\
\hline & & Carcharhiniformes & & $\mathbf{x}$ & \\
\hline & & Lamniformes & $\mathbf{x}$ & & \\
\hline & & Hexanchiformes & $\mathbf{x}$ & & \\
\hline & & Squaliformes & $\mathbf{x}$ & & \\
\hline & & Squatiniformes & $\mathbf{x}$ & & \\
\hline & & Pristiophoriformes & $\mathbf{x}$ & & \\
\hline & & Chimaeriformes & $\mathbf{x}$ & & \\
\hline & Actinopterygii & Polypteriformes & & & $\mathbf{x}$ \\
\hline & & Acipenseriformes & & $\mathbf{x}$ & \\
\hline & & Lepisosteiformes & & & $\mathbf{x}$ \\
\hline & & Amiiformes & & & $\mathbf{x}$ \\
\hline & & Osteoglossiformes & & & $\mathbf{x}$ \\
\hline & & Elopiformes & & $\mathbf{x}$ & \\
\hline & & Albuliformes & $\mathbf{x}$ & & \\
\hline & & Notacanthiformes & $\mathbf{x}$ & & \\
\hline & & Anguilliformes & & $\mathbf{x}$ & \\
\hline & & Sacccopharyngiformes & $\mathbf{x}$ & & \\
\hline & & Clupeiformes & & $\mathbf{x}$ & \\
\hline & & Gonorynchiformes & & $\mathbf{x}$ & \\
\hline & & Cypriniformes & & $\mathbf{x}$ & \\
\hline & & Characiformes & & & $\mathbf{x}$ \\
\hline & & Gymnotiformes & & & $\mathbf{x}$ \\
\hline & & Siluriformes & & $\mathbf{x}$ & \\
\hline
\end{tabular}




\begin{tabular}{|c|c|c|c|c|c|}
\hline Phylum & Class & Order & Sea & Amphi & FW \\
\hline & & Salmoniformes & & $\mathbf{x}$ & \\
\hline & & Esociformes & & & $\mathbf{x}$ \\
\hline & & Osmeriformes & & $\mathbf{x}$ & \\
\hline & & Ateleopodiformes & $\mathbf{x}$ & & \\
\hline & & Stomiiformes & $\mathbf{x}$ & & \\
\hline & & Aulopiformes & $\mathbf{x}$ & & \\
\hline & & Myctophiformes & $\mathbf{x}$ & & \\
\hline & & Lampriformes & $\mathbf{x}$ & & \\
\hline & & Polymixiiformes & $\mathbf{x}$ & & \\
\hline & & Percopsiformes & & & $\mathbf{x}$ \\
\hline & & Batracoidiformes & & $\mathbf{x}$ & \\
\hline & & Lophiiformes & $\mathbf{x}$ & & \\
\hline & & Gadiformes & & $\mathbf{x}$ & \\
\hline & & Ophidiiformes & & $\mathbf{x}$ & \\
\hline & & Mugiliformes & & $\mathbf{x}$ & \\
\hline & & Atheriniformes & & $\mathbf{x}$ & \\
\hline & & Beloniformes & & $\mathbf{x}$ & \\
\hline & & Cetomimiformes & $\mathbf{x}$ & & \\
\hline & & Cyprinodontiformes & & $\mathbf{x}$ & \\
\hline & & Stephanoberyciformes & $\mathbf{x}$ & & \\
\hline & & Beryciformes & $\mathbf{x}$ & & \\
\hline & & Zeiformes & $\mathbf{x}$ & & \\
\hline & & Gobiesociformes & $\mathbf{x}$ & & \\
\hline & & Gasterosteiformes & & $\mathbf{x}$ & \\
\hline & & Syngnatiformes & & $\mathbf{x}$ & \\
\hline & & Synbranchiformes & & $\mathbf{x}$ & \\
\hline & & Tetraodontiformes & & $\mathbf{x}$ & \\
\hline & & Pleuronectiformes & & $\mathbf{x}$ & \\
\hline & & Scorpaeniformes & $\mathbf{x}$ & & \\
\hline & & Perciformes & & $\mathbf{x}$ & \\
\hline & Sarcopterygii & Coelacanthiformes & $\mathbf{x}$ & & \\
\hline & & Ceratodontiformes & & & $\mathbf{x}$ \\
\hline & & Lepidosireniformes & & & $\mathbf{x}$ \\
\hline & Amphibia & Urodela & & & $\mathbf{x}$ \\
\hline & Mammalia & Sirenia & & $\mathbf{x}$ & \\
\hline & & Cetartiodactyla & & $\mathbf{x}$ & \\
\hline \multirow[t]{3}{*}{ Hemichordata } & Enteropneusta & Enteropneusta & $\mathbf{x}$ & & \\
\hline & Pterobranchia & Cephalodiscida & $\mathbf{x}$ & & \\
\hline & & Rhabdopleurida & $\mathbf{x}$ & & \\
\hline \multirow[t]{2}{*}{ Echinodermata } & Crinoidea & Bourgueticrinida & $\mathbf{x}$ & & \\
\hline & & Comatulida & $\mathbf{x}$ & & \\
\hline
\end{tabular}




\begin{tabular}{|c|c|c|c|c|c|}
\hline Phylum & Class & Order & Sea & Amphi & FW \\
\hline & & Isocrinida & $\mathbf{x}$ & & \\
\hline & & Millericrinida & $\mathbf{x}$ & & \\
\hline & Ophiuroidea & Euryalida & $\mathbf{x}$ & & \\
\hline & & Ophiurida & $\mathbf{x}$ & & \\
\hline & Asteroidea & Peripodida & $\mathbf{x}$ & & \\
\hline & & Brisingida & $\mathbf{x}$ & & \\
\hline & & Forcipulatida & $\mathbf{x}$ & & \\
\hline & & Spinulosida & $\mathbf{x}$ & & \\
\hline & & Notomyotida & $\mathbf{x}$ & & \\
\hline & & Paxillosida & $\mathbf{x}$ & & \\
\hline & & Valvatida & $\mathbf{x}$ & & \\
\hline & & Velatida & $\mathbf{x}$ & & \\
\hline & Echinoidea & Diadematoidea & $\mathbf{x}$ & & \\
\hline & & Echinothuroida & $\mathbf{x}$ & & \\
\hline & & Pedinoida & $\mathbf{x}$ & & \\
\hline & & Arbacioida & $\mathbf{x}$ & & \\
\hline & & Echinoida & $\mathbf{x}$ & & \\
\hline & & Phymosomatoida & $\mathbf{x}$ & & \\
\hline & & Salenioida & $\mathbf{x}$ & & \\
\hline & & Temnopleuroida & $\mathbf{x}$ & & \\
\hline & & Clypeasteroida & $\mathbf{x}$ & & \\
\hline & & Holectypoida & $\mathbf{x}$ & & \\
\hline & & Holectypoida & $\mathbf{x}$ & & \\
\hline & & Holasteroida & $\mathbf{x}$ & & \\
\hline & & Spatangoida & $\mathbf{x}$ & & \\
\hline & Holothuroidea & Apodida & $\mathbf{x}$ & & \\
\hline & & Dendrochirotida & $\mathbf{x}$ & & \\
\hline & & Elasipodida & $\mathbf{x}$ & & \\
\hline & & Holothuriida & $\mathbf{x}$ & & \\
\hline & & Molpadida & $\mathbf{x}$ & & \\
\hline & & Persiculida & $\mathbf{x}$ & & \\
\hline & & Synallactida & $\mathbf{x}$ & & \\
\hline \multirow[t]{2}{*}{ Kinorhyncha } & Kinorhyncha & Cyclorhagida & $\mathbf{x}$ & & \\
\hline & & Homalorhagida & $\mathbf{x}$ & & \\
\hline Loricifera & Loricifera & Nanaloricida & $\mathbf{x}$ & & \\
\hline \multirow[t]{4}{*}{ Priapulida } & Priapulimorpha & Priapulidae & $\mathbf{x}$ & & \\
\hline & & Tubiluchidae & $\mathbf{x}$ & & \\
\hline & & Halicryptomorpha & $\mathbf{x}$ & & \\
\hline & & Seticoronarida & $\mathbf{x}$ & & \\
\hline \multirow[t]{2}{*}{ Nematoda } & Chromadorea & Araeolaimida & & $\mathbf{x}$ & \\
\hline & & Chromadorida & & $\mathbf{x}$ & \\
\hline
\end{tabular}




\begin{tabular}{|c|c|c|c|c|c|}
\hline Phylum & Class & Order & Sea & Amphi & FW \\
\hline & & Desmodorida & $\mathbf{x}$ & & \\
\hline & & Desmoscolecida & & $\mathbf{x}$ & \\
\hline & & Monhysterida & & $\mathbf{x}$ & \\
\hline & & Plectida & & $\mathbf{x}$ & \\
\hline & & Rhabditida & & $\mathbf{x}$ & \\
\hline & Enoplea & Dorylaimida & & & $\mathbf{x}$ \\
\hline & & Mononchida & & & $\mathbf{x}$ \\
\hline & & Enoplida & & $\mathbf{x}$ & \\
\hline & & Triplonchida & & $\mathbf{x}$ & \\
\hline \multirow[t]{4}{*}{ Tardigrada } & Eutardigrada & Apochela & & $\mathbf{x}$ & \\
\hline & & Parachaela & & $\mathbf{x}$ & \\
\hline & Heterotardigrada & Arthrotardigrada & $\mathbf{x}$ & & \\
\hline & & Echiniscoidea & & $\mathbf{x}$ & \\
\hline \multirow[t]{28}{*}{ Arthropoda } & Merostomata & Xiphosura & $\mathbf{x}$ & & \\
\hline & Pycnogonida & Pantopoda & $\mathbf{x}$ & & \\
\hline & Branchiopoda & Anostraca & & $\mathbf{x}$ & \\
\hline & & Notostraca & & & $\mathbf{x}$ \\
\hline & & Cyclestherida & & & $\mathbf{x}$ \\
\hline & & Laevicaudata & & & $\mathbf{x}$ \\
\hline & & Spinicaudata & & & $\mathbf{x}$ \\
\hline & Remipedia & Nectiopoda & $\mathbf{x}$ & & \\
\hline & Cephalocarida & Brachypoda & $\mathbf{x}$ & & \\
\hline & Maxillopoda & Facetotecta & $\mathbf{x}$ & & \\
\hline & & Ascothoracida & $\mathbf{x}$ & & \\
\hline & & Pygophora & $\mathbf{x}$ & & \\
\hline & & Apygophora & $\mathbf{x}$ & & \\
\hline & & Pedunculata & $\mathbf{x}$ & & \\
\hline & & Sessilia & $\mathbf{x}$ & & \\
\hline & & Calanoida & & $\mathbf{x}$ & \\
\hline & & Cyclopoida & & $\mathbf{x}$ & \\
\hline & & Gelyelloida & & & $\mathbf{x}$ \\
\hline & & Harpacticoida & & $\mathbf{x}$ & \\
\hline & & Misophrioida & $\mathbf{x}$ & & \\
\hline & & Mormonilloida & $\mathbf{x}$ & & \\
\hline & & Platycopioida & $\mathbf{x}$ & & \\
\hline & Ostracoda & Myodocopida & & $\mathbf{x}$ & \\
\hline & & Halocyprida & $\mathbf{x}$ & & \\
\hline & & Platycopida & $\mathbf{x}$ & & \\
\hline & & Podocopida & & $\mathbf{x}$ & \\
\hline & Malacostraca & Anaspidacea & & & $\mathbf{x}$ \\
\hline & & Bathynellacea & & & $\mathbf{x}$ \\
\hline
\end{tabular}




\begin{tabular}{|c|c|c|c|c|c|}
\hline Phylum & Class & Order & Sea & Amphi & FW \\
\hline & & Amphipoda & & $\mathbf{x}$ & \\
\hline & & Cumacea & $\mathbf{x}$ & & \\
\hline & & Isopoda & & $\mathbf{x}$ & \\
\hline & & Lophogastrida & $\mathbf{x}$ & & \\
\hline & & Mictacea & $\mathbf{x}$ & & \\
\hline & & Spelaeogriphacea & & & $\mathbf{x}$ \\
\hline & & Stygiomysida & & & $\mathbf{x}$ \\
\hline & & Tanaidacea & & $\mathbf{x}$ & \\
\hline & & Thermosbaenacea & & $\mathbf{x}$ & \\
\hline & & Amphionidacea & $\mathbf{x}$ & & \\
\hline & & Decapoda & & $\mathbf{x}$ & \\
\hline & & Euphausiacea & $\mathbf{x}$ & & \\
\hline & & Stomatopoda & $\mathbf{x}$ & & \\
\hline & & Leptostraca & $\mathbf{x}$ & & \\
\hline \multirow[t]{5}{*}{ Rotifera } & Bdelloidea & Bdelloida & & $\mathbf{x}$ & \\
\hline & Monogononta & Collothecida & & & $\mathbf{x}$ \\
\hline & & Flosculariida & & & $\mathbf{x}$ \\
\hline & & Ploima & & $\mathbf{x}$ & \\
\hline & Seisonidea & Seisonida & $\mathbf{x}$ & & \\
\hline \multirow[t]{10}{*}{ Platyhelminthes } & Catenulida & Catenulida & & $\mathbf{x}$ & \\
\hline & Rhabditophora & Haplopharyngida & $\mathbf{x}$ & & \\
\hline & & Bothrioplanida & & & $\mathbf{x}$ \\
\hline & & Macrostomida & & $\mathbf{x}$ & \\
\hline & & Lecithoepitheliata & & $\mathbf{x}$ & \\
\hline & & Prolecithophora & & $\mathbf{x}$ & \\
\hline & & Proseriata & & $\mathbf{x}$ & \\
\hline & & Rhabdocoela & & & $\mathbf{x}$ \\
\hline & & Tricladida & & $\mathbf{x}$ & \\
\hline & Turbellaria & Polycladida & $\mathbf{x}$ & & \\
\hline \multirow[t]{2}{*}{ Gnathostomulida } & Gnathostomulida & Bursovaginoidea & $\mathbf{x}$ & & \\
\hline & & Filospermoidea & $\mathbf{x}$ & & \\
\hline \multirow[t]{2}{*}{ Gastrotricha } & Gastrotricha & Chaetonotida & & $\mathbf{x}$ & \\
\hline & & Macrodasyda & & $\mathbf{x}$ & \\
\hline \multirow[t]{4}{*}{ Nemertea } & Anopla & Heteronemertea & & $\mathbf{x}$ & \\
\hline & & Palaeonemertea & $\mathbf{x}$ & & \\
\hline & Enopla & Bdellonemertea & $\mathbf{x}$ & & \\
\hline & & Hoplonemertea & & $\mathbf{x}$ & \\
\hline \multirow[t]{4}{*}{ Mollusca } & Aplacophora & Caudofoveata & $\mathbf{x}$ & & \\
\hline & & Neomeniamorpha & $\mathbf{x}$ & & \\
\hline & & Pholidoskepia & $\mathbf{x}$ & & \\
\hline & Polyplacophora & Neoloricata & $\mathbf{x}$ & & \\
\hline
\end{tabular}




\begin{tabular}{|c|c|c|c|c|c|}
\hline Phylum & Class & Order & Sea & Amphi & FW \\
\hline & Bivalvia & Arcticoidea & $\mathbf{x}$ & & \\
\hline & & Cardioidea & $\mathbf{x}$ & & \\
\hline & & Chamoidea & $\mathbf{x}$ & & \\
\hline & & Clavagelloidea & $\mathbf{x}$ & & \\
\hline & & Crassatelloidea & $\mathbf{x}$ & & \\
\hline & & Cuspidarioidea & $\mathbf{x}$ & & \\
\hline & & Cyamioidea & $\mathbf{x}$ & & \\
\hline & & Cyrenoidea & $\mathbf{x}$ & & \\
\hline & & Cyneroidoidea & $\mathbf{x}$ & & \\
\hline & & Dreissenoidea & & & $\mathbf{x}$ \\
\hline & & Galeommatoidea & $\mathbf{x}$ & & \\
\hline & & Gastrochaenoidea & $\mathbf{x}$ & & \\
\hline & & Glossoidea & $\mathbf{x}$ & & \\
\hline & & Hemidonacoidea & $\mathbf{x}$ & & \\
\hline & & Hiatelloidea & $\mathbf{x}$ & & \\
\hline & & Limoidea & $\mathbf{x}$ & & \\
\hline & & Lucinoidea & $\mathbf{x}$ & & \\
\hline & & Mactroidea & $\mathbf{x}$ & & \\
\hline & & Pandoroidea & $\mathbf{x}$ & & \\
\hline & & Pholadoidea & $\mathbf{x}$ & & \\
\hline & & Pholadomyoidea & $\mathbf{x}$ & & \\
\hline & & Solenoidea & $\mathbf{x}$ & & \\
\hline & & Sphaerioidea & $\mathbf{x}$ & & \\
\hline & & Tellinoidea & $\mathbf{x}$ & & \\
\hline & & Thyrasiroidea & $\mathbf{x}$ & & \\
\hline & & Ungulinoidea & $\mathbf{x}$ & & \\
\hline & & Veneroidea & $\mathbf{x}$ & & \\
\hline & & Verticordioidea & $\mathbf{x}$ & & \\
\hline & & Trigonioidea & $\mathbf{x}$ & & \\
\hline & & Unionoidea & & & $\mathbf{x}$ \\
\hline & & Manzanelloidea & $\mathbf{x}$ & & \\
\hline & & Nuculanoidea & $\mathbf{x}$ & & \\
\hline & & Nuculoidea & $\mathbf{x}$ & & \\
\hline & & Anomioidea & $\mathbf{x}$ & & \\
\hline & & Arcoidea & $\mathbf{x}$ & & \\
\hline & & Dimyoidea & $\mathbf{x}$ & & \\
\hline & & Limoidea & $\mathbf{x}$ & & \\
\hline & & Mytiloidea & & $\mathbf{x}$ & \\
\hline & & Ostreoidea & $\mathbf{x}$ & & \\
\hline & & Pectinoidea & $\mathbf{x}$ & & \\
\hline & & Pinnoidea & $\mathbf{x}$ & & \\
\hline
\end{tabular}




\begin{tabular}{|c|c|c|c|c|c|}
\hline Phylum & Class & Order & Sea & Amphi & FW \\
\hline & & Plicatuloidea & $\mathbf{x}$ & & \\
\hline & & Pterioidea & $\mathbf{x}$ & & \\
\hline & Cephalopoda & Nautilida & $\mathbf{x}$ & & \\
\hline & & Spirulida & $\mathbf{x}$ & & \\
\hline & & Sepiida & $\mathbf{x}$ & & \\
\hline & & Sepiolida & $\mathbf{x}$ & & \\
\hline & & Teuthida & $\mathbf{x}$ & & \\
\hline & & Vampyromorphida & $\mathbf{x}$ & & \\
\hline & & Octopoda & $\mathbf{x}$ & & \\
\hline & Gastropoda & Patellogastropoda & $\mathbf{x}$ & & \\
\hline & & Neomphaloida & $\mathbf{x}$ & & \\
\hline & & Neritopsina & & $\mathbf{x}$ & \\
\hline & & Architaenioglossa & & & $\mathbf{x}$ \\
\hline & & Sorbeoconcha & $\mathbf{x}$ & & \\
\hline & & Heterostropha & $\mathbf{x}$ & & \\
\hline & & Opisthobranchia & & $\mathbf{x}$ & \\
\hline & Monoplacophora & Tryblidiida & $\mathbf{x}$ & & \\
\hline & Scaphopoda & Dentaliida & $\mathbf{x}$ & & \\
\hline & & Gadilida & $\mathbf{x}$ & & \\
\hline \multirow[t]{8}{*}{ Annelida } & Polychaeta & Amphinomida & $\mathbf{x}$ & & \\
\hline & & Eunicida & $\mathbf{x}$ & & \\
\hline & & Phyllodocida & $\mathbf{x}$ & & \\
\hline & & Scolecida & & $\mathbf{x}$ & \\
\hline & Clitellata & Arhynchobdellida & & & $\mathbf{x}$ \\
\hline & & Rhynchobdellida & & $\mathbf{x}$ & \\
\hline & Echiura & Bonelliida & $\mathbf{x}$ & & \\
\hline & & Echiurida & $\mathbf{x}$ & & \\
\hline \multirow[t]{5}{*}{ Brachiopoda } & Lingulata & Lingulida & $\mathbf{x}$ & & \\
\hline & & Discinida & $\mathbf{x}$ & & \\
\hline & Craniata & Craniida & $\mathbf{x}$ & & \\
\hline & Rhynchonellata & Terebratulida & $\mathbf{x}$ & & \\
\hline & & Rhynchonellida & $\mathbf{x}$ & & \\
\hline \multirow[t]{4}{*}{ Bryozoa } & Gymnolaemata & Cheilostomata & $\mathbf{x}$ & & \\
\hline & & Ctenostomata & & $\mathbf{x}$ & \\
\hline & Phylactolaemata & Plumatellida & & & $\mathbf{x}$ \\
\hline & Stenolaemata & Cyclostomatida & $\mathbf{x}$ & & \\
\hline Entoprocta & Entoprocta & Entoprocta & & $\mathbf{x}$ & \\
\hline \multirow[t]{4}{*}{ Porifera } & Hexactinellida & Amphidiscosida & $\mathbf{x}$ & & \\
\hline & & Amphidiscosa & $\mathbf{x}$ & & \\
\hline & & Aulocalycoida & $\mathbf{x}$ & & \\
\hline & & Hexactinosa & $\mathbf{x}$ & & \\
\hline
\end{tabular}




\begin{tabular}{|c|c|c|c|c|c|}
\hline Phylum & Class & Order & Sea & Amphi & FW \\
\hline & & Lycniscosa & $\mathbf{x}$ & & \\
\hline & & Lyssacinosa & $\mathbf{x}$ & & \\
\hline & Calcarea & Clathrinida & $\mathbf{x}$ & & \\
\hline & & Leucettida & $\mathbf{x}$ & & \\
\hline & & Murrayonida & $\mathbf{x}$ & & \\
\hline & & Baerida & $\mathbf{x}$ & & \\
\hline & & Leucosolenida & $\mathbf{x}$ & & \\
\hline & & Lithonida & $\mathbf{x}$ & & \\
\hline & & Sycettida & $\mathbf{x}$ & & \\
\hline & & Pharetronida & $\mathbf{x}$ & & \\
\hline & Homoscleromorpha & Homosclerophorida & $\mathbf{x}$ & & \\
\hline & & Astrophorida & $\mathbf{x}$ & & \\
\hline & & Spirophorida & $\mathbf{x}$ & & \\
\hline & & Haplosclerida & $\mathbf{x}$ & & \\
\hline & & Poecilosclerida & $\mathbf{x}$ & & \\
\hline & Demospongiae & Agelasida & $\mathbf{x}$ & & \\
\hline & & Axinellida & $\mathbf{x}$ & & \\
\hline & & Biemnida & $\mathbf{x}$ & & \\
\hline & & Bubarida & $\mathbf{x}$ & & \\
\hline & & Clionaida & $\mathbf{x}$ & & \\
\hline & & Desmacellida & $\mathbf{x}$ & & \\
\hline & & Haplosclerida & $\mathbf{x}$ & & \\
\hline & & Merliida & $\mathbf{x}$ & & \\
\hline & & Poeilosclerida & $\mathbf{x}$ & & \\
\hline & & Polymastida & $\mathbf{x}$ & & \\
\hline & & Scopalinida & $\mathbf{x}$ & & \\
\hline & & Sphaerocladina & $\mathbf{x}$ & & \\
\hline & & Spongillida & & $\mathbf{x}$ & \\
\hline & & Suberitida & $\mathbf{x}$ & & \\
\hline & & Tethyida & $\mathbf{x}$ & & \\
\hline & & Tetractinellida & $\mathbf{x}$ & & \\
\hline & & Trachycladida & $\mathbf{x}$ & & \\
\hline & & Chondrillida & $\mathbf{x}$ & & \\
\hline & & Chondrosiida & $\mathbf{x}$ & & \\
\hline & & Verongiida & $\mathbf{x}$ & & \\
\hline & & Dendroceratida & $\mathbf{x}$ & & \\
\hline & & Dictyoceratida & $\mathbf{x}$ & & \\
\hline \multirow[t]{4}{*}{ Ctenophora } & Nuda & Beroida & $\mathbf{x}$ & & \\
\hline & Tentaculata & Cydippida & $\mathbf{x}$ & & \\
\hline & & Lobata & $\mathbf{x}$ & & \\
\hline & & Platyctenida & $\mathbf{x}$ & & \\
\hline
\end{tabular}




\begin{tabular}{|c|c|c|c|c|c|}
\hline \multirow[t]{6}{*}{ Phylum } & Class & Order & Sea & Amphi & FW \\
\hline & & Ganeshida & $\mathbf{x}$ & & \\
\hline & & Cambojiida & $\mathbf{x}$ & & \\
\hline & & Cryptolobiferida & $\mathbf{x}$ & & \\
\hline & & Thalassocalycida & $\mathbf{x}$ & & \\
\hline & & Cestida & $\mathbf{x}$ & & \\
\hline \multirow[t]{23}{*}{ Cnidaria } & Anthozoa & Actiniaria & $\mathbf{x}$ & & \\
\hline & & Antipatharia & $\mathbf{x}$ & & \\
\hline & & Corallimorpharia & $\mathbf{x}$ & & \\
\hline & & Scleractinia & $\mathbf{x}$ & & \\
\hline & & Zoantharia & $\mathbf{x}$ & & \\
\hline & & Alcyonacea & $\mathbf{x}$ & & \\
\hline & & Helioporacea & $\mathbf{x}$ & & \\
\hline & & Pennatulacea & $\mathbf{x}$ & & \\
\hline & & Penicillaria & $\mathbf{x}$ & & \\
\hline & & Spirularia & $\mathbf{x}$ & & \\
\hline & Hydrozoa & Anthoathecata & & $\mathbf{x}$ & \\
\hline & & Leptothecata & $\mathbf{x}$ & & \\
\hline & & Siphonophorae & $\mathbf{x}$ & & \\
\hline & & Actinulida & $\mathbf{x}$ & & \\
\hline & & Limnomedusae & & $\mathbf{x}$ & \\
\hline & & Narcomedusae & $\mathbf{x}$ & & \\
\hline & & Trachymedusae & $\mathbf{x}$ & & \\
\hline & Cubozoa & Carybdeida & $\mathbf{x}$ & & \\
\hline & & Chirodropida & $\mathbf{x}$ & & \\
\hline & Staurozoa & Stauromedusae & $\mathbf{x}$ & & \\
\hline & Scyphozoa & Coronatae & $\mathbf{x}$ & & \\
\hline & & Rhizostomeae & $\mathbf{x}$ & & \\
\hline & & Semaeostomeae & $\mathbf{x}$ & & \\
\hline \multirow[t]{3}{*}{ Xenacoelomorpha } & Xenoturbella & Xenoturbella & $\mathbf{x}$ & & \\
\hline & Acoela & Acoela & $\mathbf{x}$ & & \\
\hline & Nemertodermatida & Nemertodermatida & $\mathbf{x}$ & & \\
\hline \multirow[t]{2}{*}{ Chaetognatha } & Chaetognatha & Phragmaphora & $\mathbf{x}$ & & \\
\hline & & Aphragmophora & $\mathbf{x}$ & & \\
\hline \multirow[t]{4}{*}{ Sipuncula } & Phascolosomatidea & Aspidosiphoniformes & $\mathbf{x}$ & & \\
\hline & & Phascolosomatiformes & $\mathbf{x}$ & & \\
\hline & Sipunculidea & Golfingiiformes & $\mathbf{x}$ & & \\
\hline & & Sipunculiformes & $\mathbf{x}$ & & \\
\hline
\end{tabular}

